\author{
BEATA STĘPIEŃ-ZAŁUCKA \\ ORCID: 0000-0003-1802-680X \\ Uniwersytet Rzeszowski \\ beata@kpmz.pl
}

\title{
Some remarks about the failing state of Mexico in the light of newborn dictatorships
}

\begin{abstract}
Modern Mexico is a country that has long ceased to perform its basic competences. This is particularly evident in the area of human rights protection. Decades of action by organized crime groups have led to the establishment of their power in occupied territories and, consequently, to their impunity. The social response to the crime groups' activities was the creation of areas belonging to a "warlord" in which warlords exercise their own power, unlimited by law.

In this context, several questions arise about what is currently the constitutional form of power and what form of power actually exists in Mexico, including how this power is exercised and, finally, what the current practice of human rights protection is. The answers to these questions can be found in the present article.
\end{abstract}

Keywords: Mexico's form of government, human rights, cartel dictatorship, Mexican problems.

\section{Introduction}

The United Mexican States (Estados Unidos Mexicanos) is a country in North America, covering an area of almost 2 million $\mathrm{km}^{2}$, which makes it the thirteenth largest country in the world. With approximately 106 million inhabitants, it is the eleventh largest country in the world in terms of population density. ${ }^{1}$ At the same time, Mexico is among 15 largest economies in the world and is the second-largest economy in Latin America. ${ }^{2}$ It borders the United States of America, the Pacific Ocean, the Gulf of Mexico and the Caribbean Sea, Guatemala, and Belize. It is Mexico's location that has made it an intermediary between the countries of North and South America - Mexico has become a transit country for drugs, weapons,

${ }^{1}$ Meksyk, https://pl.wikipedia.org/wiki/Meksyk (accessed: 5.11.2010).

2 P. Staszewska, P. Augustyniak, Meksyk. Przewodnik po rynku, Warszawa 2017, p. 7. 
and illegal immigrants who wanted and continue to want to enter the United States at all costs. Over the course of decades, this has led to the formation of organised groups that have worked towards this precedent. Today, however, their existence has reached a certain climax, in the face of which the Mexican state seems to be completely helpless. The state's helplessness, regardless of crime groups, has also led to the creation of territorial power enclaves. Areas over which neither the state nor the crime groups hold power have become "warlord territories."

Modern Mexico is therefore subject to the separation of powers into three constituent parts - not those that are enshrined in the Constitution, but those that are visible in the daily life of the country. There is no place for legalism, human rights, or democracy in this division. Thus, while the Constitution divides power into legislative, executive, and judicial, in practice in Mexico is split between the state, crime groups, and the warlords.

\section{Mexico and its Constitution}

Mexico operates on the basis of the Constitution of 5 February 1917, which has been amended several times. ${ }^{3}$ In the light of its provisions, Mexico is a federation of 31 states and a Federal District ${ }^{4}$ including the capital city of Mexico City, ${ }^{5}$ one of the most densely populated cities in the world. ${ }^{6}$

From a political point of view, Mexico is a republic based on the separation of legislative, executive, and judicial powers. ${ }^{7}$

The executive power is independent from the legislature and is led by the President, who is advised by the Cabinet of Ministers, officially called Ministers of State. ${ }^{8}$ The President is elected by universal suffrage for a six-year term (since 1934, previously for a four-year term), without the possibility of re-election. ${ }^{9}$ The candidate for this position must be at least 35 years old, be a Mexican citizen

3 Mexico's Constitution of 1917 with Amendments through 2015, https://www.constitutepro ject.org/constitution/Mexico_2015.pdf?lang=en (accessed: 5.11.2010), continue as the Mexican Constitution.

4 Compare art. 43 of the Mexican Constitution.

5 Compare art. 44 of the Mexican Constitution.

${ }^{6}$ Mexico is also the most populated Spanish-speaking country. In 2016, the population growth was estimated at $1.3 \%$. P. Staszewska, P. Augustyniak, op. cit., p. 10.

7 Compare art. 49 of the Mexican Constitution.

8 J. Carpizo, Características esenciales del sistema presidencial e influencias para su instauración en América Latina, "Boletín mexicano de derecho comparado" 39, 2006, no. 115, http://www. scielo.org.mx/scielo.php?script=sci_arttext\&pid=S0041-86332006000100002 (accessed: 5.11.2010).

9 More on the history of the introduction of the six-year term of office in 1904 and the reasons for maintaining this regulation in the ban on re-election, P. Fernández Barbadillo, Las vicisitudes del prin cipio de no reelección en México, p. 58 ff, https://dialnet.unirioja.es/servlet/articulo?codigo=3903142 (accessed: 5.11.2010). 
since birth, and have resided in Mexico for at least 20 years before the election. ${ }^{10}$ The current President (from 1 December 2018) is Andrés Manuel López Obrador. ${ }^{11}$ The President:

— is the head of government,

- appoints ministers, secretaries of state, and Mexican diplomatic representatives,

- is the supreme head of the armed forces, declares war and makes peace,

- issues decrees of law,

- appoints judges of the Supreme Court with the consent of the Senate,

- has a right of veto over laws passed by Congress,

- applies the law of grace. ${ }^{12}$

The legislative power is exercised by the Congress of the Union, a bicameral legislative body consisting of the Senators' Chamber (128 members, six-year term, upper house). ${ }^{13}$ and the Chamber of Deputies (500 members, three-year term, lower house). ${ }^{14}$ According to the Constitution, the competences of the Chamber of Deputies include internal affairs, ${ }^{15}$ while the Senate deals with foreign policy. ${ }^{16}$

${ }^{10}$ Compare art. 77 of the Mexican Constitution.

11 The current president, Andrés Manuel López Obrador, is called AMLO after his name and surname. More on the foundations of his presidency see: Y. Fuentes, AMLO presidente: ¿qué es la “Cuarta Transformación" que propone Andrés Manuel López Obrador para México?, https://www. bbc.com/mundo/noticias-america-latina-45712329 (accessed: 5.11.2010).

12 D. Valadés, El sistema presidencial mexicano. Actualidad y perspectivas, "Boletín mexicano de derecho comparado" 44, 2011, no. 130, http://www.scielo.org.mx/scielo.php?script=sci_arttext\&pid=S0041-86332011000100009 (accessed: 5.11.2010); A. Serra Rojas, La función constitucional del presidente de la República (1960), https://archivos.juridicas.unam.mx/www/ bjv/libros/9/4423/28.pdf (accessed: 5.11.2010). More on the issue of the responsibility of the President of Mexico see: R. Serra Cristóbal, Las responsabilidades de unjefe de estado, https://dialnet. unirioja.es/servlet/articulo?codigo=246166, p. 175 (accessed: 5.11.2010). More broadly and critically about the overly extensive presidential functions and their changes see: A. Casar, Los frenos $y$ contrapesos a las facultades del Ejecutivo; la función de los partidos políticos, el Judicial, el Legislativo y la administración pública, https://archivos.juridicas.unam.mx/www/bjv/libros/6/2748/24. pdf, pp. 401-418 (accessed: 5.11.2010); Ł. Czarnecki, Wpływ sporów konstytucyjnych na pozycje ustrojowa Prezydenta w Meksyku, "Przegląd Prawa Konstytucyjnego" 49, 2019, no. 3, p. 100 ff.

13 Compare art. 58 of the Mexican Constitution.

14 Compare art. 52 of the Mexican Constitution. More on the history of the functioning of the legislature with a strong presidential power see: J. Cortez Salinas, El Poder Legislativo en Mexico: entre la fortaleza constitucio y la debilidad politica, https://www.uam.mx/difusion/casadel tiempo/13_iv_nov_2008/casa_del_tiempo_eIV_num13_09_13.pdf, pp. 4-5, (accessed: 5.11.2010). More on the exercise of legislative power by the Senate see: A. Garita Alonso, et al., La Función Legislativa. Senado de la República, Mexico 2012, https://www.senado.gob.mx/BMO/pdfs/biblio teca_digital/nuevas_publicaciones/La_funcion_legislativa.pdf (accessed: 5.11.2010).

15 Compare art. 72 of the Mexican Constitution. L.A. Bolaños Cárdenas, El Poder Legislativo Federal. Los Acuerdos Parlamentarios y los Puntos de Acuerdo, Mexico 2016, p. 120 ff., http:// archivos.diputados.gob.mx/Centros_Estudio/UEC/prods/EL\%20PODER\%20LEGISLATIVO\%20 FEDERAL.pdf (accessed: 5.11.2010).

16 Compare art. 73 of the Mexican Constitution. 
According to article 94 of the Mexican Constitution, the judicial power of the United Mexican States is vested in the Supreme Court of Justice, the Electoral Court, specialised circuit courts, unitary circuit courts, and the district courts. ${ }^{17}$

\section{The real picture of democracy and respect for human rights in Mexico}

Unfortunately, the real political picture of Mexico is very different. Everything seems to point to the fact that contemporary Mexico is a failed state. Although in the "Fragile States Index" it has 69.7 points (2019 data), ${ }^{18}$ Mexico is no longer fulfilling its competences. The rationale behind this is that in some regions democracy has collapsed - above all, in Mexico nothing similar to an absolute protection of human rights has existed for a long time, as I will try to show with further examples from the last decade alone.

The first example of the lack of respect for human rights and the state's withdrawal from their protection will be the city of Allende, where hundreds of people have died at the hands of the cartel and the state simply looked at it passively and did nothing at that time to protect the citizens. Another case will be the Ayotzinapy students - here I will show how far cartel power and corruption in Mexico reaches. The final example, which I will use to show a true picture of the cartels' power and the true realization of human and civil rights in Mexico, will be the real conditions in which the 2018 election campaign was held.

It is noteworthy, however, that the first two events described here, and a whole series of indescribable events that took place between 2010 and 2015, have led to the tightening of regulations on counteracting corruption and organised crime groups, but this applies only to the normative matter.

One such regulation was the introduction of amendments to 14 provisions of the Mexican Constitution, which allowed the implementation of the National Anti-Corruption System in 2015. ${ }^{19}$ The essence of this system is to provide a legal framework for supervision of public officials and private entities in the context of fighting against corruption and bribery. The National Anti-Corruption System coordinates actions at federal, state, and municipal levels in order to prevent,

17 More on the selection of 11 Supreme Court judges see: R. López Tarango, Suprema Corte de Justicia de la Nación de México y debates obresu reforma, p. 7 ff., https://dialnet.unirioja.es/descarga/ articulo/1705661.pdf (accessed: 5.11.2010).

18 World Data Atlas, Mexico — Fragile states index, https://knoema.com/atlas/Mexico/topics/ World-Rankings/World-Rankings/Fragile-states-index (accessed: 5.11.2010).

19 Compare art. 22, 28, 41, 73, 74, 76, 79, 104, 108, 109, 113, 114, 116 and 122. "Decreto por el quesere forman, adicionan y derogan diversas disposiciones de la Constitución Política de los Estados Unidos Mexicanos, en materia de combate a la corrupción. Publicado en el Diario Oficial de la Federación el 27 de mayo de 2015”, http://www.diputados.gob.mx/LeyesBiblio/proceso/ docleg/62/223_DOF_27may15.pdf (accessed: 20.11.2020). 
detect, and prosecute corruption offences. ${ }^{20}$ On the basis of this constitutional law regulation, a comprehensive system for combating corruption in the country has been established. ${ }^{21}$ The system is based on the General Law of the National Anti-Corruption System, ${ }^{22}$ the General Law on Administrative Liability, ${ }^{23}$ the Organic Law of the Federal Court of Administrative Justice, ${ }^{24}$ the Federal Law on Audit and Responsibility, ${ }^{25}$ and the reformed Organic Law of the General Prosecutor's Office, ${ }^{26}$ the Federal Criminal Code. ${ }^{27}$ and the Organic Law of the Federal Public Administration. ${ }^{28}$ Another law that was reformed at that time was the law of 7 November 1996, the Federal Law Against Organised Crime.

After 2015 the law changed for the better, but in practice the state of democracy and human rights, despite legislative changes, has deteriorated in favour of the created dictatorships. In this example, the current strength of these dictatorships in the 2018 elections is visible, and what is clear is the violation of article 29 of the Mexican Constitution, which establishes the protection of the right to life. ${ }^{29}$

\section{The city of Allende}

The year 2011 is considered to be the beginning of Mexico's downfall in the current decade. It revealed the state's complete powerlessness in dealing with the drug cartels. The small town of Allende, a 40-minute drive from the Texas border, was attacked by bandits from the Zetas Cartel, one of the most violent drug

20 D. Márquez, Mexican administrative law against corruption: Scope and future, "Mexican Law Review" 8, 2015, p. 75 ff. https://www.elsevier.es/en-revista-mexican-law-review-123-articulo-mexican-administrative-law-against-corruption-S1870057815000050 (accessed: 20.11.2020).

${ }^{21}$ Compare art. 113 of the Mexican Constitution. L.D. Martínez Corres, et al., Mexico: At a turning point in anti-corruption investigations and enforcement, https://globalinvestigationsre view.com/review/the-investigations-review-of-the-americas/2020/article/mexico-turning-point-inanti-corruption-investigations-and-enforcement (accessed: 20.11.2020).

${ }^{22}$ Ley General del Sistema Nacional Anticorrupciónel 18 de julio de 2016, http://www.di putados.gob.mx/LeyesBiblio/pdf/LGSNA.pdf (accessed: 20.11.2020).

23 Ley General de Responsabilidades Administrativa el 18 de julio de 2016, http://www.di putados.gob.mx/LeyesBiblio/pdf/LGRA_130420.pdf (accessed: 20.11.2020).

24 Ley Orgánica del Tribunal Federal de Justicia Administrativa, el 18 de julio de 2016, http:// www.diputados.gob.mx/LeyesBiblio/pdf/LOTFJA.pdf (accessed: 20.11.2020).

${ }^{25}$ Ley de Fiscalización y Rendición de Cuentas de la Federación, el 18 de julio de 2016, http:// www.diputados.gob.mx/LeyesBiblio/pdf/LFRCF.pdf (accessed: 20.11.2020).

26 Enmienda Ley Orgánica de la Procuraduría General de la República, el 18 de julio de 2016, http://www.diputados.gob.mx/LeyesBiblio/abro/lopgr_2009/LOPGR_abro.pdf (accessed: 20.11.2020).

27 Enmienda Código Penal Federal el 18 de julio de 2016, http://www.diputados.gob.mx/Leyes Biblio/ref/cpf/CPF_ref129_18jul16.pdf (accessed: 20.11.2020).

28 Enmienda Ley Orgánica de la Administración Pública Federal, http://www.diputados.gob. mx/LeyesBiblio/ref/loapf/LOAPF_ref54_18jul16.pdf (accessed: 20.11.2020).

29 Compare art. 29 of the Mexican Constitution. 
trafficking organisations. The criminals demolished the town by killing hundreds of men, women, and children in revenge for the interference of the American Drug Enforcement Administration (DEA), which obtained cellphone identification numbers to track down the two most wanted cartel bosses, Miguel Ángel Treviño and his brother Omar. Paradoxically, Zetas quickly realised and planned retaliation against the inhabitants of the city from which they suspected the DEA had obtained information. The city authorities as well as the police remained passive to the massacre against the inhabitants. The inhabitants could neither defend themselves nor even count on any police interference. Throughout the years after the massacre, Mexican authorities conducted a perfunctory, superficial investigation into the matter. A monument to the victims was even erected in Allende, without fully explaining what had happened to them, without establishing the guilty parties, without punishing anyone. ${ }^{30}$ Although a decade has passed since then, no one has been indicted or charged, although every government has assured that the guilty parties will be found and punished.

\section{The students from Ayotzinapa}

However, the most shocking symbol of Mexico's collapse as a democratic state, defending and protecting human and civil rights and freedoms at all costs, is the case of 43 students at the Ayotzinapa Pedagogical School in Guerrero. The students took the bus to protest against a city mayor when they were detained by the city guards and then handed over to a local cartel with whom the mayor was probably associated. Unfortunately, the students went missing without a trace. ${ }^{31}$ After the disappearance, people organized marches and protests, which ended relatively quickly. Although Mexicans have not forgotten the tragedy, those responsible for - most probably — burning the students in a landfill have gone unpunished. ${ }^{32}$

This is an example of close cooperation between the cartels and the local authorities, who instead of defending their citizens handed the students over to criminals, not caring about their lives or the responsibilities of the authorities, seeking only their own gain, connected in corruption.

${ }^{30}$ La tragedia olvidada de Allende: un fin de semana que dejó desaparecidos, muertos y destrucción a manos de los Zetas, https://www.infobae.com/america/mexico/2019/06/27/la-tragedia-olvidada-de-allende-un-fin-de-semana-que-dejo-desaparecidos-muertos-y-destruccion-a-manos-de-los-zetas/ (accessed: 5.11.2010).

31 BBC News Service, Mexico missing students: Suspect detained in 2014 case, https://www. bbc.com/news/world-latin-america-53234925 (accessed: 5.11.2010); L. Melesio, Case of 43 Ayotzinapa missing students unresolved five years on, https://www.aljazeera.com/features/2019/9/26/ case-of-43-ayotzinapa-missing-students-unresolved-five-years-on (accessed: 5.11.2010).

32 A.G. Rojas, Ayotzinapa: qué pasó con el caso de los 43 estudiantes desaparecidos (explicado en 100 y 300 palabras), https://www.bbc.com/mundo/noticias-america-latina-49820325, (accessed: 7.11.2010). 
Of course, we can say that a lot of time has passed since this tragedy occurred, or that it was a one-off "incident". However, the main problem in Mexico is that by not explaining cases like these only resulted in further consolidating the cartels' power. This in turn has led to the deepening of Mexico's decline as a democratic state where human and civil rights and freedoms are realized.

\section{The 2018 election campaign}

Among other examples is the extent of political assassinations before the last elections in Mexico on 1 July 2018, in which the president, two chambers of parliament, and councillors were elected - more than 18,000 representatives in total. However, it is not important how many deputies were elected, but in what conditions.

Juana Irais Maldonado was a Green Party candidate for the position of councillor in the city of Puebla, but she was assassinated. Her car came under fire when she was returning from an election meeting with her colleague. ${ }^{33}$

Pamela Teran, in turn, was murdered when she was leaving a restaurant election meeting with her co-worker, driver, and photographer. ${ }^{34}$

When Fernando Purón finished the election debate with his rivals in the border town of Piedras Negras, he went to his voters to take a selfie with them. At that moment he was shot in the head. Purón was the 112th politician murdered in Mexico since September 2017. ${ }^{35}$

These facts may be shocking, but Mexico's problem is that the fate of Juan Irais Maldonado, Pamela Teran, or Fernando Purón does not befall selective candidates, but hundreds of them. Some sources estimate that more than 132 or even 145 politicians were killed during the last election campaign in Mexico. ${ }^{36}$

33 Fiscalia de pueblainvestigahomicidio de candidata Juana Irais Maldonado, https:// www.24-horas.mx/2018/06/02/fiscalia-de-puebla-investiga-homicidio-de-candidata-juana-iraismaldonado/ (accessed: 10.11.2010); Asesinan a unacandidata a diputada y regidora en México, https://telesistema11.com.do/arte-y-medio/espectaculo/asesinan-a-una-candidata-a-diputada-yregidora-en-mexico (accessed: 10.11.2010).

34 Cae segundo implicado en triple homicidio, https://oaxaca.eluniversal.com.mx/seguridad/27 -05-2019/cae-segundo-implicado-en-asesinato-de-la-candidata-pamela-teran (accessed: 10.11.2010); Dan con presuntoasesino de Pamela Terán y María del Sol, https://www.semanariolosperiodistas. $\mathrm{mx} /$ dan-con-presunto-asesino-de-pamela-teran-y-maria-del-sol/ (accessed: 10.11.2010); Detienen a asesino de Pamela Teran y fotoperiodista Maria del Sol, https://lasillarota.com/detienen-asesinomaria-del-sol-oaxaca-juchitan/243817 (accessed: 10.11.2010).

${ }^{35}$ Mexican candidate shot while posing for selfie in latest murder of politician, https://www.theguardian.com/world/2018/jun/12/mexico-election-politicians-killed-fernando-puron-selfie (accessed: 10.11.2010).

36 A. Diaz, J. Campis, Mexico goes to the polls this weekend. 132 politicians have been killed since campaigning began, per one count, https://edition.cnn.com/2018/06/27/americas/mexico-po litical-deaths-election-season-trnd/index.html (accessed: 10.11.2010). At least 145 politicians killed in run-up to Mexico elections, https:/www.efe.com/efe/english/world/at-least-145-politicians-kil led-in-run-up-to-mexico-elections/50000262-3672104 (accessed: 10.11.2010). 
Importantly, this is not just the case for politicians, as Mexico is considered one of the most dangerous countries for the journalistic profession. Only Afghanistan and Syria are ahead of it. Since 2000 more than 100 journalists have died in Mexico. ${ }^{37}$

\section{Cartel dictatorships}

This state of affairs automatically raises the question of what kind of government allows the fate of the political candidates as well as current officials to be decided not by the candidates themselves or by their voters, but by the cartels. What is worse, the cartels have a real impact on the election results. In my opinion, there is only one phrase to describe a state where it is not the government that holds real power, but organised crime - this is a failed state. And the form of government, on the other hand, is a "novel" sounding "dictatorship" of the drug cartels.

A secondary question can be asked. How is it possible that modern Mexico is not fulfilling its functions, which is most shocking in the field of human rights protection? Well, in Mexico, the boundaries between the government and its bodies and their functions, the police, politicians, business and crime organisations have blurred. Because organised crime infiltrates every possible level and authority, in practice, as the writer Jorge Ibargüengoitia writes in his Instructions for life in Mexico: "Don't call the police if you have problems, because you will have more of them." ${ }^{38}$ As a result, the aggressors are not only representatives of organised crime, but also politicians, businessmen, police officers, and others who work with organised crime. Therefore, investigations are not carried out properly and do not yield any results, because neither senior politicians, nor policemen, nor prosecutors and judges strive to eliminate organised crime. ${ }^{39}$ In practice, this means that three out of four crimes are unreported. Of the remaining $25 \%$ of reported crimes, only about $4.55 \%$ end up being investigated, and only $1.6 \%$ of the total number of crimes committed are brought to court. In other words, for every 100 crimes committed in Mexico, only 1.6 end up in court. This means that impunity reaches an appalling $99 \%$ — which is why Mexico is described as an empire of impunity. This is due to on the one hand, to the enormous scale of corruption and, on the other hand the fear for one's life and that of one's family. The years of organised crime have led to crime groups developing their own structures, which are evolving (hence the transformation among the cartels), but

${ }^{37}$ M. Müller, A. Saéz, Mortal danger for Mexico's reporters, https://www.dw.com/en/mortaldanger-for-mexicos-reporters/av-48896864 (accessed: 10.11.2010).

38 J. Ibargüengoitia, Instrucciones para vivir en México, Mexico 1991.

39 G. Bataillon, Narco trafico y corrupcion: las formas de la violencia en Mexico en el siglo XXI, "Nueva Sociedad" 2015, no. 255, pp. 54-68, https://nuso.org/articulo/narcotrafico-y-corrupcion -las-formas-de-la-violencia-en-mexico-en-el-siglo-xxi/ (accessed: 12.11.2010). 
also, importantly, the representatives of organised groups have reached all levels of government, as I have mentioned above. ${ }^{40}$

The drug cartels that once lived mainly from drug trafficking have today expanded their activities. Each cartel has its own territory, which it controls ruthlessly, exercising dictatorial power over it. Drug trafficking has become one of the sources of income. Others include usury, ${ }^{41}$ theft, including the theft of state fuel, robbery, kidnapping for ransom, and above all extortion, which is collected from lemon producers, small shopkeepers, and mining companies alike. ${ }^{42}$

Therefore, the boundaries between criminals, law enforcement agencies, and the judiciary or politicians are blurred. As a result, organised groups promote politicians and politicians rule the warped groups, although there is no official evidence of this. At least apart from the fact that between 2005 and 2019 the war between the cartels and the state claimed at least 275,000 lives and 73,200 "missing", whose mass graves are almost constantly being discovered in Mexico. ${ }^{43}$

Such a large number of victims (without statistics from last year, which I will present below) is due to the fact that there are currently 196 organised crime groups. On 7 June 2020, 117 murders were recorded within 24 hours - the most brutal day of the year. The previous record was on April 20, when 114 people died. If this trend continues, 2020 could become the bloodiest year in Mexican history. ${ }^{44}$

\section{5. "Warlord" dictatorship}

The last question to be asked is whether this is how the entire Mexican state works. No - there are places in Mexico where organised crime has been dealt with, although by illegal means. These are areas managed by rich landowners, the "warlords." These owners rent external protection to protect their land. The task of protection is to defend against organised crime groups and eliminate any threat to the "warlord." An example of such a town is Tancitaro in Michoacan, where

40 M. Carbonell, Corrupción judicial e impunidad: el caso de México, pp. 1-2, https://archi vos.juridicas.unam.mx/www/bjv/libros/6/2770/4.pdf (accessed: 10.11.2010).

41 One reason for the struggle between Colombia and Mexico is that Colombians lend money to small Mexican merchants ("drop to drop"). However, Mexican groups try to eliminate the Colombian competition. La impunidadalimento "gota a gota”, https:/www.connectas.org/especiales/ gota-gota-america-latina/index.html@p=2658.html (accessed: 10.11.2010).

42 CJNG y Cártel de Sinaloa: dos organizaciones criminales dominan el mapa del narco en México, https://www.infobae.com/america/mexico/2020/08/14/cjng-y-cartel-de-sinaloa-dos-orga nizaciones-criminales-dominan-el-mapa-del-narco-en-mexico/ (accessed: 12.11.2010).

43 Mexico murder rate hits record high in 2019, https://www.aljazeera.com/news/2020/01/21/ mexico-murder-rate-hits-record-high-in-2019/ (accessed: 12.11.2010). M.E. Franco, Mexico reeling over 73,000 missing, according to new numbers, https://www.nbcnews.com/news/latino/mexicoreeling-over-73-000-missing-according-new-numbers-n1233767 (accessed: 12.11.2010).

${ }^{44}$ CJNG y Cártel de Sinaloa... 
one of the bloodiest Familia cartels operates. (although one must realise that there are many more such places, about 30). ${ }^{45}$

This state of affairs shows profoundly that a desperate society seeking protection from organised crime stopped looking for state aid and abandoned the law in favour of introducing its own rules, and thus created another dictatorship. It is a dictatorship based not on the organised drug cartels, but on the rule of warlord governments. In practice, the real power on warlord territories lies in the hands of a "growers' council" which holds it by means of armed groups, which "clean up in their name and in their interests."

\section{Summary}

Today, Mexico is a country with an entirely different form of government from that of the Constitution and law Acts. The simplest term to describe this form is "anarchy," but it would be too general and too vague. This is due to the fact that Mexico is divided between the cartels, the warlords, and the actual state authorities. The cartels and the warlords exercise a dictatorship on their territories, which of course does not mean that there are no battles for territory between them. Hundreds of thousands of people have died in these battles, and judging by the estimates, this year will bring a record in terms of fatalities

All this has led to a secret CIA report on Mexico in 2018, some parts of which have been accessed by both scientists and journalists. The report states that drug trafficking groups have gained effective control over about $20 \%$ of Mexico. In the last two years the number of homicides has risen to its highest level in six decades; the homicide rate in Mexico is more than four times higher than in the United States, and this year the number of victims has already exceeded 77,000. Mexico is facing hundreds of internally displaced people fleeing violence - its current state is seen as the biggest crisis in Latin America since the "dirty wars" during the 1970s and 1980s. The point of this report is to ask the Americans of the State Department to avoid travelling to half of Mexico's states, five of which have been described as dangerous, at the same level as Syria, Afghanistan, and Iraq. ${ }^{47}$

The real collapse of the Mexican state in favour of the cartels is visible in the pandemic, where the most needy are reached not by state aid, but by the cartels,

45 M. Fisher, A. Taub, Building a mini-state with avocados and guns, https://www.nytimes. com/2018/01/18/world/americas/mexico-drug-war-tancitaro.html (accessed: 12.11.2010); Vigilantes cut deal with Mexican gov't, https://www.sandiegouniontribune.com/en-espanol/sdhoy-vigilan tes-cut-deal-with-mexican-govt-2014apr15-story.html (accessed: 12.11.2010).

46 M. Fisher, A. Taub, op. cit.

47 An example of information about executions in Mexico which reached the Polish media is the execution of three men. E. Kolecka, Brutalna egzekucja. Nie żyja koledzy „El Chapo”, https:// www.o2.pl/informacje/brutalna-egzekucja-nie-zyja-koledzy-el-chapo-6560691005860704a (accessed: 12.11.2010). 
who deliver food and supplies — rice, sugar, flour, beans, or soap — by trucks to hundreds of people standing in long queues. ${ }^{48}$

Usually, when finishing their deliberations, academics make an assessment of or forecast for the described condition. However, in my opinion, the best evaluation of Mexico is the actual situation presented here. When making a forecast for Mexico, I will not be optimistic. Today, after years of the cartels consolidating their influence and warlords controlling many territories, no one wants to give up power. This, in turn, can have only so many results in the coming years - an intensification of the struggle for territory, a deepening of the human rights crisis, and perhaps even the breakup of the Mexican state.

\section{Bibliography}

Asesinan a unacandidata a diputada y regidora en México, https://telesistema11.com.do/arte-y-medio/ espectaculo/asesinan-a-una-candidata-a-diputada-y-regidora-en-mexico (accessed: 10.11.2010).

At least 145 politicians killed in run-up to Mexico elections, https:/www.efe.com/efe/english/ world/at-least-145-politicians-killed-in-run-up-to-mexico-elections/50000262-3672104 (accessed: 10.11.2010).

Bataillon G., Narco trafico y corrupcion: las formas de la violencia en Mexico en el siglo XXI, "Nueva Sociedad" 2015, no. 255, pp. 54-68, https://nuso.org/articulo/narcotrafico-y-corrupcionlas-formas-de-la-violencia-en-mexico-en-el-siglo-xxi/ (accessed: 12.11.2010).

BBC News Service, Mexico missing students: Suspect detained in 2014 case, https://www.bbc.com/ news/world-latin-america-53234925 (accessed: 5.11.2010).

Bolaños Cárdenas L.A., El Poder Legislativo Federal. Los Acuerdos Parlamentarios y los Puntos de Acuerdo, Mexico 2016, http://archivos.diputados.gob.mx/Centros_Estudio/UEC/prods/ EL\%20PODER\%20LEGISLATIVO\%20FEDERAL.pdf (accessed: 5.11.2010).

Cae segundo implicado en triple homicidio, https://oaxaca.eluniversal.com.mx/seguridad/27-05-20 19/cae-segundo-implicado-en-asesinato-de-la-candidata-pamela-teran (accessed: 10.11.2010).

Carbonell M., Corrupción judicial e impunidad: el caso de México, https://archivos.juridicas.unam. $\mathrm{mx} / \mathrm{www} / \mathrm{bjv} / \mathrm{libros} / 6 / 2770 / 4 . p d f$ (accessed: 10.11.2010).

Carpizo J., Características esenciales del sistema presidencial e influencias para su instauración en América Latina, "Boletín mexicano de derecho comparado" 39, 2006, no. 115, http://www.scie lo.org.mx/scielo.php?script=sci_arttext\&pid=S0041-86332006000100002 (accessed: 5.11.2010).

Casar A., Los frenos y contrapesos a las facultades del Ejecutivo; la función de los partidos politicos, el Judicial, el Legislativo y la administración pública, pp. 401-418, https://archivos. juridicas.unam.mx/www/bjv/libros/6/2748/24.pdf (accessed: 5.11.2010).

CJNGy Cártel de Sinaloa: dos organizaciones criminales dominan el mapa del narco en México, https:// www.infobae.com/america/mexico/2020/08/14/cjng-y-cartel-de-sinaloa-dos-organizacionescriminales-dominan-el-mapa-del-narco-en-mexico/ (accessed: 12.11.2010).

Cortez Salinas J., El Poder Legislativo en Mexico: entre la fortaleza constitucio y la debilidad politica, https://www.uam.mx/difusion/casadeltiempo/13_iv_nov_2008/casa_del_tiempo_eIV_ num13_09_13.pdf (accessed: 5.11.2010).

48 B. Sheridan, Los grupos criminales de México controlan cadavez más territorio, https:// www.lanacion.com.ar/el-mundo/los-grupos-criminales-mexico-controlan-cada-vez-nid2493649 (accessed: 12.11.2010).

Studia nad Autorytaryzmem i Totalitaryzmem 42, nr 4, 2020

(C) for this edition by CNS 
Czarnecki Ł., Wplyw sporów konstytucyjnych na pozycję ustrojową Prezydenta w Meksyku, "Przegląd Prawa Konstytucyjnego" 49, 2019, no. 3.

Dan con presuntoasesino de Pamela Terán y María del Sol, https://www.semanariolosperiodistas. $\mathrm{mx} /$ dan-con-presunto-asesino-de-pamela-teran-y-maria-del-sol/ (accessed: 10.11.2010).

Decreto por el quesere forman, adicionan y derogan diversas disposiciones de la Constitución Política de los Estados Unidos Mexicanos, en materia de combate a la corrupción. Publicado en el Diario Oficial de la Federación el 27 de mayo de 2015, http://www.diputados.gob.mx/ LeyesBiblio/proceso/docleg/62/223_DOF_27may15.pdf (accessed: 20.11.2020).

Detienen a asesino de Pamela Teran y fotoperiodista Maria del Sol, https://lasillarota.com/detienenasesino-maria-del-sol-oaxaca-juchitan/243817 (accessed: 10.11.2010).

Diaz A., Campis J., Mexico goes to the polls this weekend. 132 politicians have been killed since campaigning began, per one count, https://edition.cnn.com/2018/06/27/americas/mexico-po litical-deaths-election-season-trnd/index.html (accessed: 10.11.2010).

Enmienda Código Penal Federal el 18 de julio de 2016 (18 july 2016), http://www.diputados.gob. $\mathrm{mx} /$ LeyesBiblio/ref/cpf/CPF_ref129_18jul16.pdf (accessed: 20.11.2020).

Enmienda Ley Orgánica de la Administración Pública Federal, http://www.diputados.gob.mx/ LeyesBiblio/ref/loapf/LOAPF_ref54_18jul16.pdf (accessed: 20.11.2020).

Enmienda Ley Orgánica de la Procuraduría General de la República, el 18 de julio de 2016 (18 july 2016), http://www.diputados.gob.mx/LeyesBiblio/abro/lopgr_2009/LOPGR_abro.pdf (accessed: 20.11.2020).

Fernández Barbadillo P., Las vicisitudes del principio de no reelección en México, https://dialnet. unirioja.es/servlet/articulo?codigo=3903142 (accessed: 5.11.2010).

Fiscalia de puebla investiga homicidio de candidata Juana Irais Maldonado, https://www.24-horas. mx/2018/06/02/fiscalia-de-puebla-investiga-homicidio-de-candidata-juana-irais-maldonado/ (accessed: 10.11.2010).

Fisher M., Taub A., Building a mini-state with avocados and guns, https://www.nytimes.com/2018/ 01/18/world/americas/mexico-drug-war-tancitaro.html (accessed: 12.11.2010).

Franco M.E., Mexico reeling over 73,000 missing, according to new numbers, https://www.nbcnews. $\mathrm{com} /$ news/latino/mexico-reeling-over-73-000-missing-according-new-numbers-n1233767 (accessed: 12.11.2010).

Fuentes Y., AMLO presidente: ¿qué es la "Cuarta Transformación” que propone Andrés Manuel López Obrador para México?, https://www.bbc.com/mundo/noticias-america-latina-45712329 (accessed: 5.11.2010).

Garita Alonso A., Selene A., Hernández H., López García M., Álvarez J. M., Montaña Ramírez L. M., Montoya Arroyo R. O., La Función Legislativa. Senado de la República, Mexico 2012, https:// www.senado.gob.mx/BMO/pdfs/biblioteca_digital/nuevas_publicaciones/La_funcion_legis lativa.pdf (accessed: 5.11.2010).

Ibargüengoitia J., Instrucciones para vivir en México, Mexico 1991.

Kolecka E., Brutalna egzekucja. Nie żyją koledzy „,El Chapo”, https://www.o2.pl/informacje/brutal na-egzekucja-nie-zyja-koledzy-el-chapo-6560691005860704a (accessed: 12.11.2010).

La impunidad alimento "gota a gota", https://www.connectas.org/especiales/gota-gota-america-la tina/index.html@p=2658.html (accessed: 10.11.2010).

La tragedia olvidada de Allende: un fin de semana que dejó desaparecidos, muertos y destrucción a manos de los Zetas, https://www.infobae.com/america/mexico/2019/06/27/la-tragediaolvidada-de-allende-un-fin-de-semana-que-dejo-desaparecidos-muertos-y-destruccion-amanos-de-los-zetas/ (accessed: 5.11.2010).

Ley de Fiscalización y Rendición de Cuentas de la Federación, el 18 de julio de 2016, http://www. diputados.gob.mx/LeyesBiblio/pdf/LFRCF.pdf (accessed: 20.11.2020).

Ley General del Sistema Nacional Anticorrupciónel 18 de julio de 2016, http://www.diputados.gob. mx/LeyesBiblio/pdf/LGSNA.pdf (accessed: 20.11.2020). 
Ley General de Responsabilidades Administrativa el 18 de julio de 2016, http://www.diputados.gob. mx/LeyesBiblio/pdf/LGRA_130420.pdf (accessed: 20.11.2020).

Ley Orgánica del Tribunal Federal de Justicia Administrativa, el 18 de julio de 2016, http://www. diputados.gob.mx/LeyesBiblio/pdf/LOTFJA.pdf (accessed: 20.11.2020).

López Tarango R., Suprema Corte de Justicia de la Nación de México y debatesobresu reforma, https://dialnet.unirioja.es/descarga/articulo/1705661.pdf (accessed: 5.11.2010).

Márquez D., Mexican administrative law against corruption: Scope and future, "Mexican Law Review" 8, 2015, pp. 75-100, https://www.elsevier.es/en-revista-mexican-law-review-123-articulomexican-administrative-law-against-corruption-S1870057815000050 (accessed: 20.11.2020).

Martínez Corres L.D. et al., Mexico: At a turning point in anti-corruption investigations and enforcement, https://globalinvestigationsreview.com/review/the-investigations-review-of-the-americas/ 2020/article/mexico-turning-point-in-anti-corruption-investigations-and-enforcement (accessed: 20.11.2020).

Meksyk, https://pl.wikipedia.org/wiki/Meksyk (accessed: 5.11.2010).

Melesio L., Case of 43 Ayotzinapa missing students unresolved five years on, https://www.aljazeera. com/features/2019/9/26/case-of-43-ayotzinapa-missing-students-unresolved-five-years-on (accessed: 5.11.2010).

Mexico murder rate hits record high in 2019, https://www.aljazeera.com/news/2020/01/21/mexicomurder-rate-hits-record-high-in-2019/ (accessed: 12.11.2010).

Müller M., Saéz A., Mortal danger for Mexico's reporters, https://www.dw.com/en/mortal-dangerfor-mexicos-reporters/av-48896864 (accessed: 10.11.2010).

Rojas A.G., Ayotzinapa: qué pasó con el caso de los 43 estudiantes desaparecidos (explicado en 100 y 300 palabras), https://www.bbc.com/mundo/noticias-america-latina-49820325, (accessed: 7.11.2010).

Serra Cristóbal R., Las responsabilidades de unjefe de estado, https://dialnet.unirioja.es/servlet/ articulo? codigo $=246166$ (accessed: 5.11.2010).

Serra Rojas A., La función constitucional del presidente de la República (1960), https://archivos. juridicas.unam.mx/www/bjv/libros/9/4423/28.pdf (accessed: 5.11.2010).

Sheridan B., Los grupos criminales de México controlan cadavez más territorio, https:/www.lana cion.com.ar/el-mundo/los-grupos-criminales-mexico-controlan-cada-vez-nid2493649

Staszewska P., Augustyniak P., Meksyk. Przewodnik po rynku, Warszawa 2017.

Valadés D., El sistema presidencial mexicano. Actualidad y perspectivas, "Boletín mexicano de derecho comparado", http://www.scielo.org.mx/scielo.php?script=sci_arttext\&pid=S0041-8633 2011000100009 (accessed: 5.11.2010).

Vigilantes cut deal with Mexican gov't, https://www.sandiegouniontribune.com/en-espanol/sdhoyvigilantes-cut-deal-with-mexican-govt-2014apr15-story.html (accessed: 12.11.2010).

World Data Atlas, Mexico - Fragile states index, https://knoema.com/atlas/Mexico/topics/World -Rankings/World-Rankings/Fragile-states-index (accessed: 12.11.2010). 